九州大学学術情報リポジトリ

Kyushu University Institutional Repository

The Relation between the Fall in Breeding

Success Ratio of Mountain Hawk Eagle (Spizaetus nipalensis) and Forest Structure of its Home Range

I ida, Tomohiko

Graduate School of Bioresource and Bioenvironmental Science, Kyushu University

Mori, Takayuki

Faculty of Agriculture, Graduate school, Kyushu University

Inoue, Susumu

Faculty of Agriculture, Graduate school, Kyushu University

https://doi.org/10.5109/9245

出版情報: 九州大学大学院農学研究院紀要. 51 (2)，pp.293-301，2006-10-27. Faculty of Agriculture, Kyushu University

バージョン :

権利関係 : 


\title{
The Relation between the Fall in Breeding Success Ratio of Mountain Hawk Eagle (Spizaetus nipalensis) and Forest Structure of its Home Range
}

\author{
Tomohiko IIDA ${ }^{1}$, Takayuki MOHRI ${ }^{2}$ and Susumu INOUE ${ }^{3}$
}

\author{
Laboratory of Forest Resource Management, Division of Forest Ecosphere Sciences and \\ Management, Department of Forest and Forest Products Sciences, \\ Graduate School of Bioresource and Bioenvironmetal Science, \\ Kyushu University, Fukuoka 812-2415, Japan \\ (Received June 30, 2006 and accepted July 24, 2006)
}

\begin{abstract}
The kumatakas' breeding success ratio of the western Hiroshima prefecture has fallen rapidly as another of bird of prey reported since 1990s. The author has studied the relation between the success ratio and the vegetation in the home range for 25 years to make clear the reasons why its ratio have dropped recently. Firstly the author has confirmed that the ratio has kept near 100\% in 1980s, and its level have fallen about 50\% in 1990s and many kumataka couldn't breed in 2000s. Secondly the author has confirmed the home range of three site of the kumataka. The area of site A is 635 hectares, site B is 839 hectares and site $\mathrm{C}$ is 1,108 hectares. Thirdly vegetation within the range divided 10 categories and data would be related to the success ratio have been collected. The author has analyzed these data and divided the usable vegetation (forest) and un-usable one. The former categories consisted mainly under 10 years artificial forest, broad leaf forest, harvested area and so on, the latter categories contained mainly over 10 years artificial forest and forest without care. Forest cares, such as thinning, pruning and tending are very important roles to keep their success ratio. Finally the author made clearly conclusion as follow. (1) Wide area of the under 10 year artificial forests and broad-leaved forests were existed in 1980s. (2) Un-usable forest area for the kumataka have increased and exceeded usable forest area. (3) Un-usable area of site A has counted less than 400 hectares since 1990s. (4) Usable area should be kept over 400 hectares for maintenance breeding success ratio. (5) Usable area needs over a half of the home range. (6) If forestry activities, such as harvesting, thinning, pruning and so on, shall be carried out the level of 1980s, its ratio shall go up to higher level like the 1990s. (7) Rehabilitation of forestry is the important matter for the kumataka.
\end{abstract}

\section{INTRODUCTION}

Mountain hawk eagle (MHE; Spizaetus nipalensis) is divided three (3) subspecies and has distributed just southeastern part of coastal Asian, such as Sri Lanka, southern part of India, Taiwan and Japan. The distribution area is quit small and its group is one of the scare species. While one of which named Kumataka $(S . n$. orientali) by Japanese lives only in Japan. The environment agency (EA) of Japan would like to say special Japan-subspecies (EA, 1991). The latest survey expected that kumataka live only about 1,800 heads in Japan (Japanese Society of Preservation of Bird (JSPB), 2004). This number of heads are as many over three (3) time as Golden Eagle (GE; Aquila chrysaetos japon$i c a$ ) which have been living comparatively same condition was estimated just 200 260 couples (400 520 heads). However, many scientists and researchers worried on fall in breeding success ratio of kumataka (Iida,

\footnotetext{
${ }^{1}$ Laboratory of Forest Resource Management, Division of Forest Ecosphere Sciences and Management, Department of Forest and Forest Products Sciences, Graduate School of Bioresource and Bioenvironmetal Science, Kyushu University

${ }^{2}$ Laboratory of Zoology, Division of Zoology and Entomology, Department of Applied Genetics and Pest Management, Faculty of Agriculture, Graduate school, Kyuyshu University

${ }^{3}$ Laboratory of Forest Resources Management, Division of Forest Ecosphere Sciences and Management, Department of Forest and Forest Products Sciences, Faculty of Agriculture, Graduate School, Kyushu University

* Corresponding author (E-mail: tiida@bronze.ocn.ne.jp / sinoue@forest.kyushu-u.ac.jp)
}

1996; JSPB, 2004) like the GE (Society of Research of the Golden Eagle (SRGE) 2001). If this bird will be disappeared from Japan, one species shall be ruined. By the way, the breeding success ratio is calculated percentage of numbers of couples has bred for total numbers of couples surveyed as SRGE has done (SRGE, 2001).

The breeding success ratio of kumataka has fallen from $47 \%$ in 1980 s to $23 \%$ in the second half of 1990 s (SRGE, 2001). Therefore, the author has worried that kumataka will be an extinct species. The survey of kumataka hadn't done as detail as GE. Some monitoring surveys have been carrying out since early 1980s in the Hiroshima pref. According this survey, the breeding success ratio of kumataka had been kept 86\% (average of five years) in early 1980s, but it dropped $37 \%$ in the first half of 1990s, and in 1996 it come down further at 8\% (Iida, 1996). The survey on the breeding success ratio carried out at another prefectures, such as Miyazaki, Nara and Yamagata prefecture, and every place showed that the ratio recorded fall in (JSPB, 2004). Accordingly, fall in the ratio is not special phenomenon of Hiroshima prefecture but important issues of the whole Japan.

So far it was pointed out that the fall of the breeding success ratio of kumataka was affected by the human being activities at the area where kumataka have been lived (Fujita, 1996). However these indications didn't sufficiently approve yet. On the other hand, eggs survey for contamination of organic chlorite compounds hasn't also shown so high degrees. Decrease of feed 
animals was expected another important factor of fall in the ratio (Iida, 1996; JSPB, 2004). But the real factors didn't clearly understand for many scientists. So the author has surveyed the reasons why kumataka had fallen their breeding success ratio in the Hiroshima prefecture.

\section{METHODS}

\section{Survey area and actual breeding state}

The survey has carried out from 2003 to 2005 in the southwestern part of Hiroshima prefecture. And some data collected before 2002 were added. The recent 5 years breeding success ratio in area surveyed is very low. For example, 35 couples are confirmed in western part of Hiroshima prefecture, but 28 couples ( $80 \%$ of total couples) have succeeded their breeding with just less than one (1) time within five(5) year. It means that less than $16 \%$ (80\%/5 year) of kumataka in the area have bred just one bird per year.

Before the survey started, we selected three (3) sites. Two of them (named A and B) are lower breeding success places, but it is normal areas today. The other one (named C) is higher success place where located northwestern part of Hiroshima prefecture. The kumataka of site $\mathrm{C}$ has bred almost every year. Every site is located at steep mountain area with deep valley. The site A and B situated at Hiroshima city in southern part of Hiroshima prefecture, and the breeding success ratio have been dropped suddenly since 1990s. The nests (site A and B) were confirmed by watchers at 1981 (site A) and 1983 (site B). On the other hand, the site $\mathrm{C}$ located at Akiohta-machi in northern part of Hiroshima prefecture. The nest of the site $\mathrm{C}$ was found at 2001and the author confirmed that breeding has succeeded at 2001, 2002.

The altitude of site $\mathrm{A}$ is 200 900 meters from the sea level, and site B is 200 700 meters. The topography of site $\mathrm{A}$ is rather one top of mountain isolated from northern parts, and streams along the valleys around the mountain formed like a horseshoe. The site B located in mountains along the tributary of the Ohta-gawa.

Vegetation of both sites are mainly covered with planted Japanese cider (Cryptomeria japonica D. Don) and/or planted Japanese cypress (Chamaecyparis obtusa Shieb. et Zucc.), distributed with natural and man-made Japanese red pine (Pinus densiflora Sieb. et Zucc.) and broad-leaved trees composed oak (Quercus serrata Thunb.) and another species. Both sites included small villages which resident used the sites for their lives. Compare to artificial forest ratio of both sites, site A was about $65 \%$ at 1990 , on the other hand, site B was about $85 \%$ and there were older cider and cypress forests than site A. The site B was a wood production area in Hiroshima prefecture. One plot size of forest at site $\mathrm{A}$ is rather smaller than site B, however one bigger plot found at the ridge of mountains. At the site B has generally bigger size plots. The National Forest (NF) located along the ridge of mountain of site $\mathrm{A}$ and mid of the site $\mathrm{B}$. The ratio of the NF for total forest is around $20 \%$ of site $\mathrm{A}$ and $10 \%$ of site $\mathrm{B}$.

The site $\mathrm{C}$ located from around 500 to 1,000 meters from the sea level. Vegetation of the area is covered about 50\% with deciduous forests included oak (Quercus species). And planted cider, cypress and natural red pine forests disperse in the natural deciduous forest. The size of the one plot is not so big but so small. Big size plots distributed only along the ridge of mountain. There isn't the National Forest.

\section{Home range survey}

The home range survey started before 2002. Firstly the author decided the basic survey point where researchers observed kumataka. Secondly researchers watched activities of kumataka and made another 5 8 survey points for one couple of kumataka. However sometimes researchers carried out the moving survey with activities of kumataka. Thirdly researchers distinguished the kumataka surveyed or the other one. At the same time, we recorded flight routs, display activities (demonstration activities), hunting activities and so on. If the kumataka perched on a branch, the author trys to confirmed reasons why did it choose that place and how did it use that point. Finally the home range was determined by using collected data.

The home range was decided by maximum range of activities (EA, 1996). This range comprised every place the bird used during the survey time, two years data. In this case, the data are used for analysis the relation between breeding situation and forest composition. The area of home range was decided with unit area of forest compartment or sub-compartment (data were made by the Hiroshima prefecture and revised every 5 year). The home range calculated area of all forest compartment and non forest area where kumataka has used for breeding.

\section{Breeding survey}

The surveys have done every year for confirming success of their breeding. In generally, period of the breeding showed display-activities, sang special voices around their nest and sometimes researchers could see they mated. If they laid egg, it should be confirmed at the nest. Couple's activities around nest will be increased.

Late May, if we found that the couple bird carrying feeds for infant bird, the survey shall be continued. If watchers couldn't find activities of taking feed for their child, researchers should analyze the reasons why did this kumataka faile breeding. If researchers found the branches with green leaves in the nest, we recognized that this failure had happened at the stage of construction of the nest. If we confirmed that the kumatak sit on their egg, the failure had happened at the sit on egg stage. If an infant bird was found in the nest or activities for taking feeds was watched, the failure had happened at the infant breeding stage.

If a couple birds continued their works for breeding to coming January, the author recognized the success of breeding. The breeding success ratio of Hiroshima pre- 
fecture has been made by the Mountain Hawk Eagle Society of Hiroshima (MHESH) and Iida, the head of this society, announced the data at 1996, the other data also announced by JSPB at 2004.

\section{Vegetation survey in the home range and its dynamics}

We made three study sites vegetation maps to understand the reasons why the breeding success ratio dropped recently. The maps have drawn using stand assessment and forest stand map produced by the Hiroshima prefecture and Hiroshima regional office of the National Forest.

While the maps' data renewed every five years, it didn't accord with the survey year of the bird and vegetation data collected. While there isn't fit data (same yeas data), we used the aerial photograph to confirm the vegetation and finally expected the condition with before and after data. The 2005 years' vegetation map of site A and B substituted 2002 years' data and site C also used 2003 years' which was the latest data of stand assessment. These maps confirmed with field survey.

The maps were made every five to ten years since 1980s which kumataka has been surveyed. For example the maps were made as of 1980, 1983, 1990, 2000 and 2005. It means that the author has carried out the home range survey for 25 years. However the map of site $\mathrm{C}$ was as of 1990, 2000, 2003 and 2005, due to find the nest at 2001.

For analysis how did kumataka use forests, we classified ten types of main vegetation, such as (1) under 5 years of cider and cypress planted, (2) 5 10 years cider and cypress planted, (3) over 10 years cider and cypress planted, (4) Japanese red pine forest, (5) fir forest, (6) broad-leafed forest, (7) glass land, (8) harvested forest, (9) land slide area and (10) the other land use (village area, rice field and so on). The home range areas (each site of A, B and C) were counted by the classified vegetation to be recorded in the stand assessment.

\section{Field survey on the over ten years artificial forest}

The most influence vegetation type for breeding success within the ten classified is the third one, that is over 10 years artificial cider and cypress forest. In generally kumataka can't work at this age of artificial forests, due to too thick with trees and branches. However bird watchers can sometimes find kumataka in the same categorized forests where it has wide space for kumataka to be able to fly easily inside the forest. On this context, the over ten years artificial cider and cypress forests should be surveyed whether it has appropriate spaces for kumataka or not.

The survey method is as follows. Firstly the survey plots were chosen within typical places of the over ten years artificial cider and cypress forest. Secondly just 100 square meters plots were selected at random in the typical places. The shape of this 100 square meters plot was a radius 5.64 meters circle. Thirdly the researchers have counted total number of trees within the plot and measured distance of tree.

\section{Survey of feeds animals for kumataka}

Some feed animals of kumataka have been known (Morimoto \& Iida, 1992; Morioka et al., 1995). Typical middle-size feed animals are hare (Lepus brachyurus) and copper pheasant (Phasianus soemmerringii) in the home range. The survey on these two feeds has done with following method.

\section{(1) Hare survey}

The hare survey has carried out with counting number of droppings from $5^{\text {th }}$ to $7^{\text {th }}$ of November in 2005. This survey has done at the following categories. The site A, B and C, and (a) less than five years artificial forests, (b) 6〜10 years artificial forest, (c) over ten years artificial forests and (d) broad-leaved forests. The researchers have decided two plots at each category forest, and they counted the number of droppings as Yamada did in 1988 (Yamada, 1988).

\section{(2) Copper pheasant survey}

The copper pheasant survey had done with line census method in 2003 and 2004. The line census was carried out along a 3.5 meters width and unpaved forest road. Length of the line is about one kilometers and researchers walk from at seven to ten o'clock in the morning and from three to six o'clock in the afternoon and counted number of heads watched. One way counted one time. If they go and back the same road, they kept over 30 minutes interval.

\section{RESULTS}

\section{Home range survey}

The basic home range of site A was determined its boundary with addition data of 1985 and 1989, and site B was also determined the boundary with addition data of 1994 and 1998.

The site A located at mountain isolated, and just one couple live in the site. The range usually depends on the big ridge and isolated another couple. It doesn't change the range so much year by year. On the other hand the site B surrounded by steep mountains except northern part with rice field. It is far distance from the boundary of the range to the ridge of the northern mountains. Another couple lives at the northern part where the home range overlaps. The range boundary of eastern and southern part is very clear, because of being big mountains. But northern and western part of range isn't so clearly, due to lack of big mountain ridge. The range of northern and western side changed some small places year by year.

The site $\mathrm{C}$ was difficult to confirm the boundary of the range, because the researchers found this couple rather late and survey-time was a bit short. But the basic range was clearly understood by having been confirmed flight routs of the bird, perch and so on. Finally we determined the range with outskirt big ridges located western and eastern part of the nest and with places where researchers found the bird at north and south valley. This is the same manner for deciding the home range of kumataka (Sudo, 1985; Morimoto \& Iida, 1992).

As the result, the area of site A counted 
635 hectares, the site B is 839 hectares and the site $\mathrm{C}$ is 1,108 hectares.

\section{Degradation of breeding success ratio}

The kumataka of Hiroshima prefecture had kept high ratio of the breeding success in early 1980s, most cases would achieve nearly 100 percent of success. However it dropped about 50 percent at the late 1980s. And it further fallen in $90 \mathrm{~s}$, and it has been less than 10 percent at the late half 90s (Fig. 1).

The kumataka of the site A and B have same situations, for example both kept nearly 100 percent of success until early 80s, but it dropped 50 percent in late $80 \mathrm{~s}$ and it became one success at several years in $90 \mathrm{~s}$. Further more researchers couldn't find any new child bird at the site A since 1991 and at the site B also since 2000. On the other hand, the site $\mathrm{C}$ was found a nest at 2001, and researchers confirmed three times success of breeding since 2001 (Table 1).

Many failure cases couldn't make clearly yet, but some of which depend on human being activities, for example three cases of site A (note 1, 2, 3 of table 1). The site B case supposed to be too old of male bird to hatch (note 4 of Table 1). And the most cases out of explanation above were expected at the period of nest making stage.

\section{Vegetation and forest structure}

It was shown the site A's chart of the vegetation change of every three to five years for sample. The author confirmed five main vegetation types at the site A (Fig 2₫3-1). One of which was broad-leafed type forest. The area of that type forest was counted 197 hectares (31 percent of total area of the range) at 1980. However its area reduced 182 hectares (28\%) at 1990 and these area continued to 2005. The over ten years artificial cider and cypress forests were followed by broad-leafed forest and calculated 173 hectares (27\%) at 1980 , but this forest types increased to 402 hectares (63\%) at 2000. To the contrary, area of the under 10 years artificial cider and cypress forest reduced from 73 hectares (11\%) at 1980 to nothing at 2000. The less than five years artificial forests also have reduced from 73 hectares (11\%) to 3 hectares (0\%) at 2000. The Japanese red pine forests kept their area, from 55 hectares (8\%) at 1980 to 47 hectares at 2000. Log production carried out, and 14 hectares (2\%) were planted. Consequently old aged forests areas increased and less than 10 years younger forests reduced within 20 years time.

The researchers confirmed ten types vegetation in the site B (Fig. 3-2). The widest vegetation type of the site B was over ten years artificial cider and cypress forests at 1980 , it calculated 638 hectares (76\% of total area of site B). But this type of vegetation increased to 705 hectares (84\%) at 2000. The vegetation types shared over ten percent except above artificial forest in the site B couldn't find. The second largest vegetation type was the under five years artificial cider and cypress, its area was 67 hectares (8\%) at 1980 and
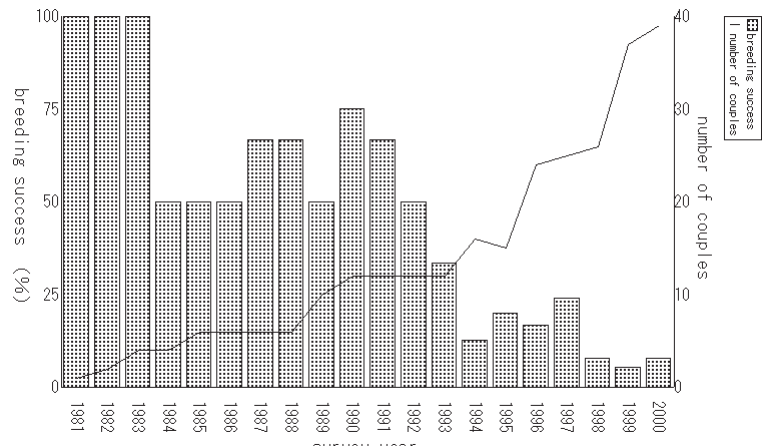

$$
\text { survey year }
$$

Fig. 1. Trend of the breeding success ratio of kumataka in Hiroshima prefecture.

Table 1. The breeding situation at three survey sites

\begin{tabular}{|c|c|c|c|}
\hline year & & survey si & \\
\hline 1980 & $\mathrm{~A}$ & B & $\mathrm{C}$ \\
\hline 81 & $\bigcirc$ & $\bigcirc$ & \\
\hline 82 & $\bigcirc$ & $\bigcirc$ & \\
\hline 83 & $\bigcirc$ & $\bigcirc$ & \\
\hline 84 & \# note 1 & 0 & \\
\hline 85 & $\bigcirc$ & $\bigcirc$ & \\
\hline 86 & $x$ \# note 2 & $\bigcirc$ & \\
\hline 87 & $\times$ \# note 3 & $\bigcirc$ & \\
\hline 88 & $\times \# \#$ & $\bigcirc$ & \\
\hline 89 & $\bigcirc$ & $\bigcirc$ & \\
\hline 1990 & $\times \# \#$ & $\bigcirc$ & \\
\hline 91 & $\bigcirc$ & $\times \# \#$ & \\
\hline 92 & $\times \# \#$ & $\bigcirc$ & \\
\hline 93 & $\times \# \#$ & $\times \# \#$ & \\
\hline 94 & $\times \# \#$ & $\bigcirc$ & \\
\hline 95 & $\times \# \#$ & $\times \# \#$ & \\
\hline 96 & $\times \# \#$ & $\times \# \#$ & \\
\hline 97 & $\times \# \#$ & $\times$ \# note 4 & \\
\hline 98 & $\times \# \#$ & note 5 & \\
\hline 99 & $\times \# \#$ & $\times \# \#$ & \\
\hline 2000 & $\times \# \#$ & $\bigcirc$ & \\
\hline 01 & $\times \# \#$ & $\times \# \#$ & $\bigcirc$ \\
\hline 02 & $\times$ \#\#\# note 6 & $\times \# \#$ & $\times \# \#$ \\
\hline 03 & $\times \# \# \#$ & $\times \# \#$ & $\bigcirc$ \\
\hline 04 & $\times \# \# \#$ & $\times \# \#$ & $\bigcirc$ \\
\hline 05 & $\times \# \# \#$ & $\times \# \#$ & $\times \# \#$ \\
\hline
\end{tabular}

legent: $\bigcirc$ success of breeding, $\times$ failing of breeding \# sitting of egg stage \#\# nest made stage \#\#\# adhered to the nest

note 1; at sitting egg stage, felling trees started in front of the nest forest.

note 2 ; at the sitting egg stage, human being invaded in nest forest.

note 3 ; at the sitting egg atage, pruning started near the nest forest.

note 4; about 75 days sit egg, but it didn't incuvated. the old female desappered in summer.

note 5 ; changed female to new one, new couple succeeded breeding.

note 6 ; the nest had been lost, but this couple adhered to the nest forest. 

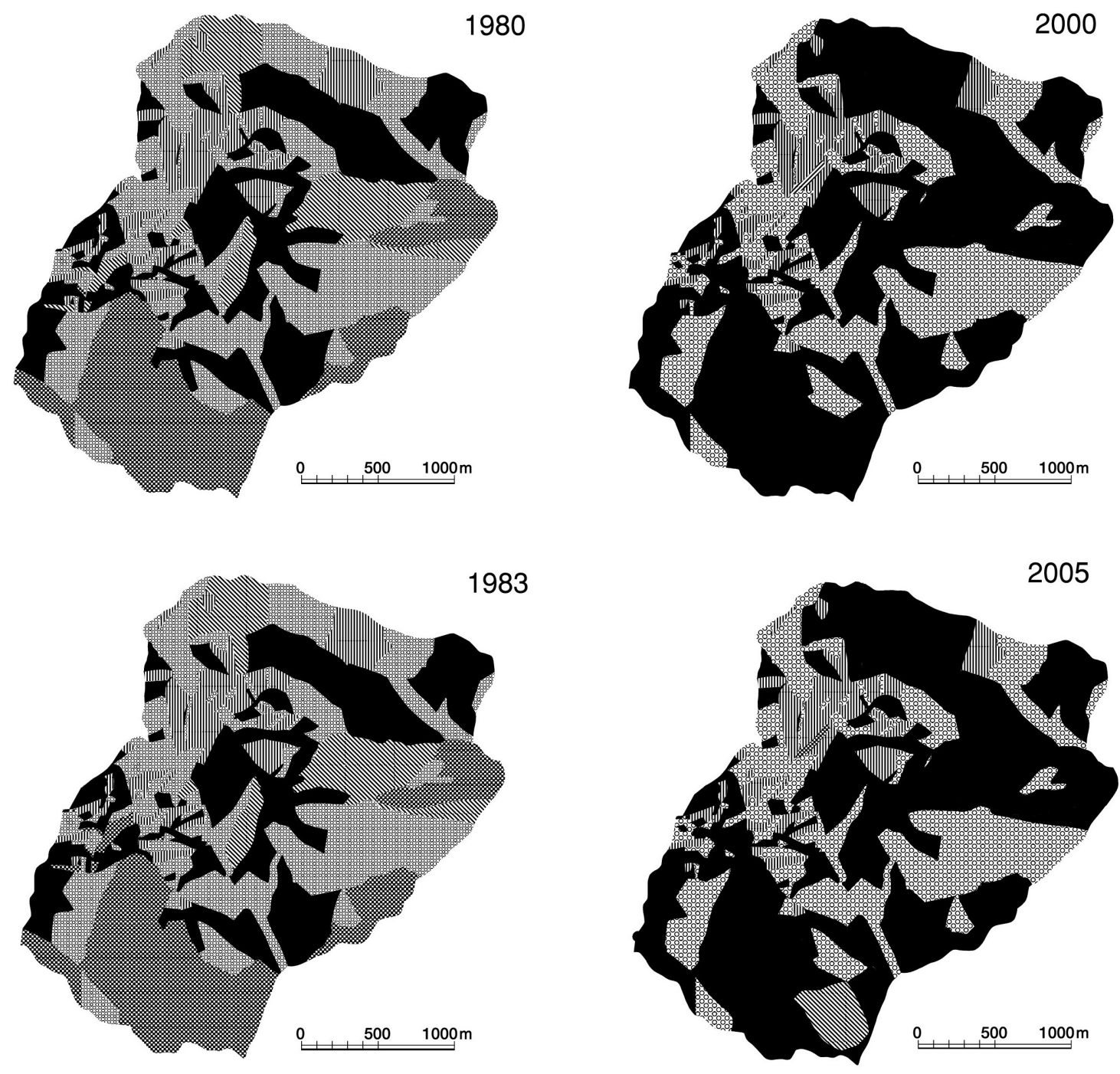

1990

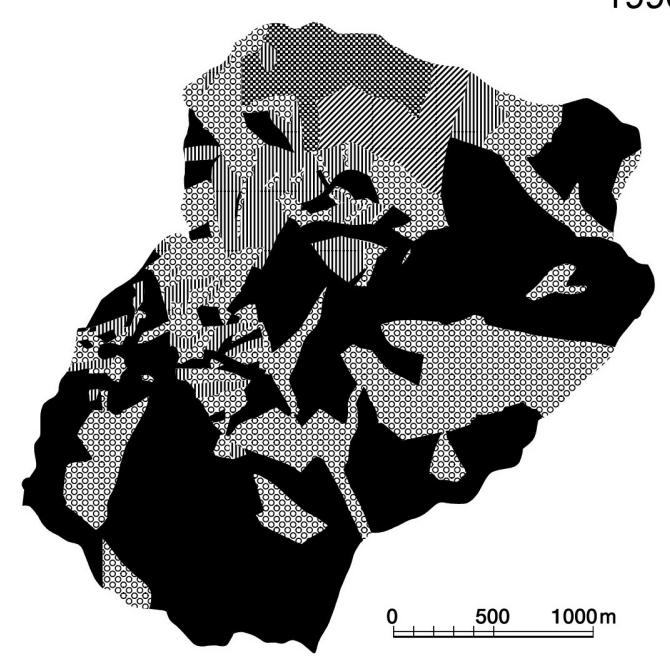

legend

under 5 yr artificial forest

$6 \sim 10$ yr artificial forest

over 10 yr artificial forest

Japanese red pine forest

broad-leafed forest

the other

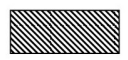

Fig. 2. The vegetation-change over the years at the site A. 


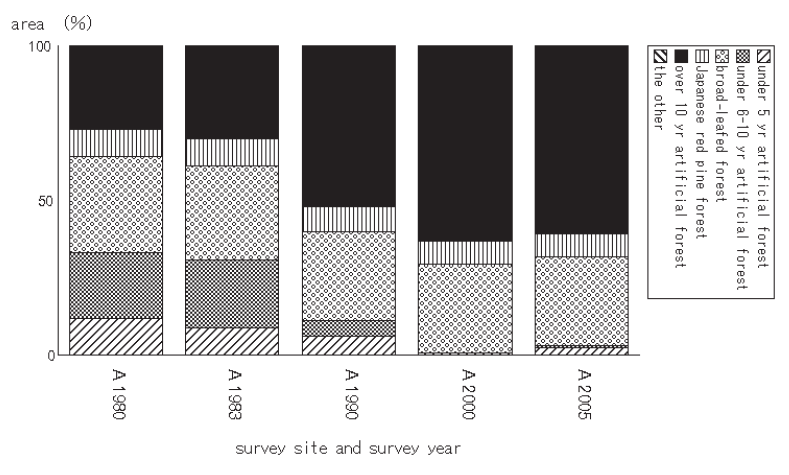

Fig. 3₫1. The area by vegetation types at the site A.

Category of the under 5 years artificial forest, the $6 \sim 10$ years artificial forest and red pine forest are usable area for kumataka. But the over 10 years artificial forest is un-usable forest.

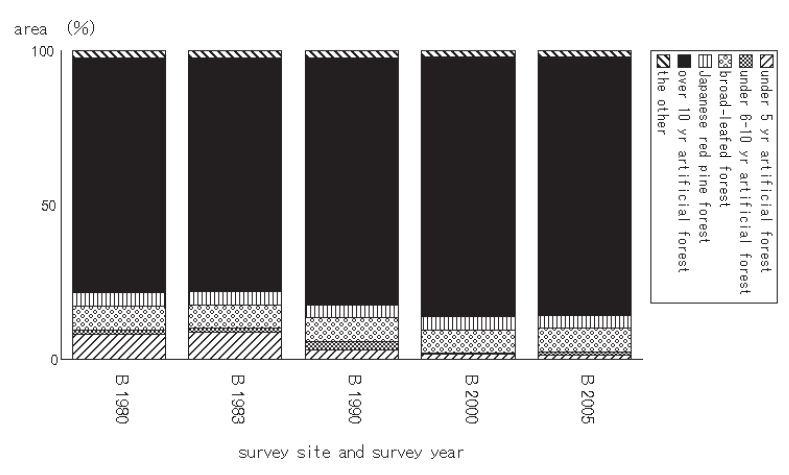

Fig. 3ロ2. The area by vegetation types at the site B.

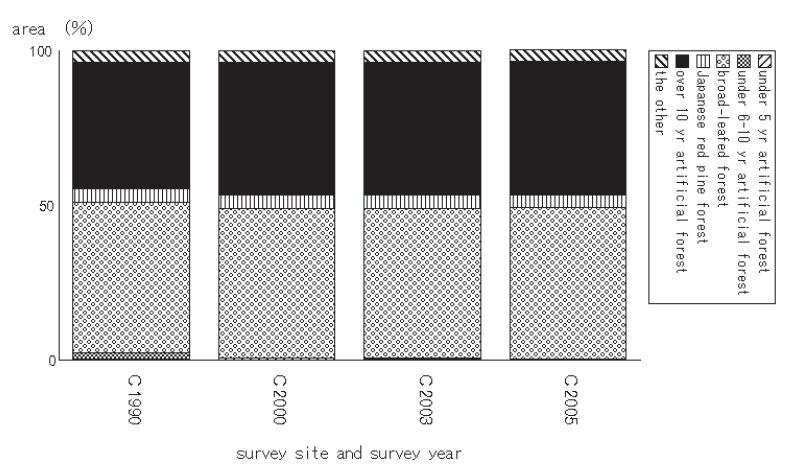

Fig. 3ロ3. The area by vegetation types at the site C.

reduced 8 hectares (1\%) at 2005 .

There were verified six types of vegetation at the site C (Fig. 3-3). The widest area were covered by broad-leaved forests at 1990, its area was 541 hectares (48\% of the site area). This vegetation kept a top area at every survey years and decreased only small area to 537 hectares at 2005. Followed vegetation was the over ten years artificial cider and cypress forest have been calculated 456 hectares (41\%) at 1990 and 480 hectares (43\%) at 2005. The third was a Japanese red pine for- est, and that area was 46 hectares (4\%) from 1990 to 2005.

The characteristic of the vegetation of three sites are as followed. The under ten years artificial forest are distributed in the site A with the largest area, followed the site $\mathrm{B}$ followed and the site $\mathrm{C}$ was the lowest. But these young artificial forests have decreased gradually. For example, in the case of site A and B, these sites have kept the vegetation data since 1980s, the less than ten years younger vegetation have remained about 30 percent at the site A at 1980s and about 10 percent at the site $\mathrm{B}$ at same period. The younger vegetation ratio were down about a half of 80s in 1990s. And in 2000s, most younger forest grew up and new plantation have been done a little. Although researchers found small area of young artificial forest at the site C, but most of them also grew up. To the contrarily, the over ten years artificial forest increased and its ratio attained the maximum. The Japanese red pine and the broad leaf forest didn't change so far and its area is about 10 percent of the home range at site $\mathrm{B}$, on the other hand, its area shared about 30 percent in site A and over 50 percent in site $\mathrm{C}$.

The over 10 years old artificial forest have shared almost same ratio in the site $\mathrm{A}$ and $\mathrm{C}$, and the researchers confirmed that a $7 \sim 8$ trees have been calculated at the 100 square meters (5.64 meters circle) survey plot in this artificial forest. However only $2 \sim 3$ trees at the 100 square meters plot have been found at site B. The number of trees in the site B are sparse than site A and C (Fig. 4).

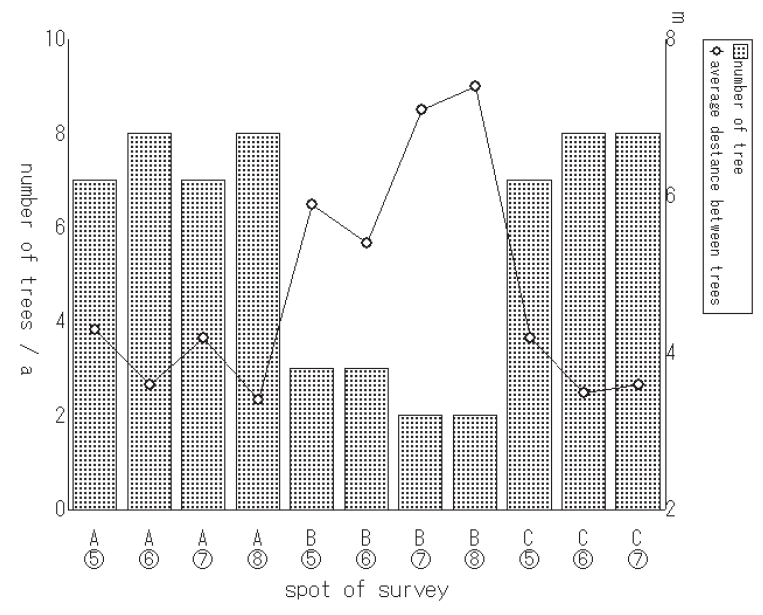

Fig. 4. Number of trees and average destance between trees in 100 square meters polt at the over 10 years artificial forest.

\section{Feed animals habitation survey (1) Droppings of hare}

The number of droppings of hare was big difference by three sites. The largest number were counted at the site $\mathrm{B}$, followed by site $\mathrm{C}$. The smallest number of droppings was at the site A. The researchers could not find droppings at some vegetation in site A (Fig. 5). Especially, the droppings have been found a little at the over ten years artificial forest. To the contrary, the 


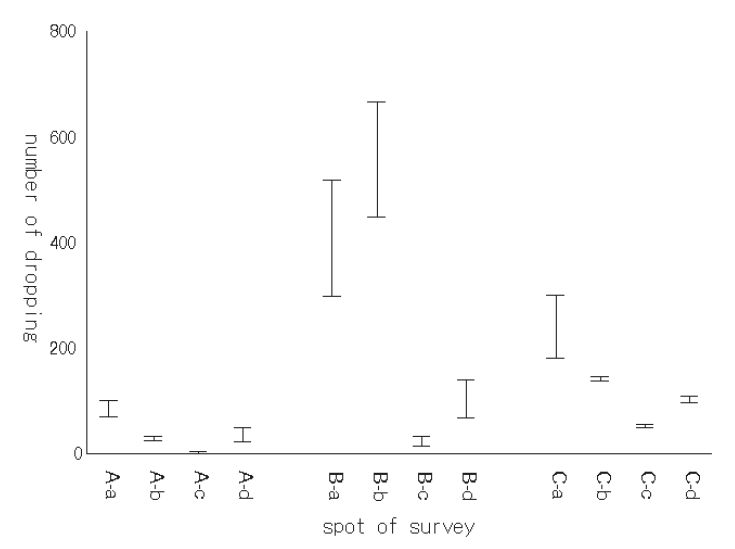

Fig. 5. The number of droppings in the main vegetation at the survey sites.

plot size: 100 square meters

survey plot number; two for every main vegetation main vegetation type;

(a) under 5 year artificial cider and cypress forest

(b) 6 10 year artificial cider and cypress forest

(c) over 10 year artificial cider and cypress forest

(d) broad-leafed forest

largest number of droppings were found at the younger artificial forest. And at broad-leafed forest it were reported some numbers.

Distributing state of droppings divided some types. The under ten years artificial forest was a gathering type. Droppings often gathered at one place and it was sometimes counted over 100 peaces at once. But the droppings distributed sparsely at the broad-leafed forest, and was found a state of one by one at the over ten years artificial forest.

When the author checked the dropping number, he understood that the largest number in the over ten years artificial forest was at the site C, followed B and lastly A. However these number of droppings of older forests were less than younger forest one. And the number at the broad-leafed forest was reported that the site $\mathrm{B}$ had the largest number, followed $\mathrm{C}$ and finally $\mathrm{A}$.

\section{(2) Number of copper pheasant}

The copper pheasant survey carried out 2003 and 2004. The appearance index (ratio of appearance heads confirmed to number of time surveyed) calculated. The highest index showed at the site B, and it was 52.6 at 2003 and 47.7 at 2004 (Table 2).

Table 2. The apperence index of copper pheasant by sites and survey year

\begin{tabular}{ccccr}
\hline year & site & survey time & $\begin{array}{c}\text { number of } \\
\text { heads counted }\end{array}$ & index \\
\hline 2003 & A & 12 & 1 & 8.3 \\
2003 & B & 38 & 20 & 52.6 \\
2003 & C & 12 & 4 & 33.3 \\
2004 & A & 12 & 0 & 0.0 \\
2004 & B & 44 & 21 & 47.7 \\
2004 & C & 10 & 2 & 20.0 \\
\hline
\end{tabular}

note: index $=$ number of heads counted/survey times $\times 100$

\section{DISCUSSION}

To understanding the reason why the breeding ratio has been dropping recently, we expected some influences such as big reservoir construction, road and the other development works surround the nest place. But we confirmed that big development activities didn't carry out near at site A and B since 1980s. And we also could not understand influences at site A and B by human being activities, except three cases of site A at late 1980s. However the breeding ratio have fallen.

In the cases of our survey site, western part of Hiroshima prefecture, the kumataka had bred every year in 1980s. But its ratio have fallen every two years in 1990s and further dropped to every several years since late 1990s. The survey of kumataka at the Nara prefecture is one of a few places where the survey has been continuing since early 1980s. Seven couples were recorded that the breeding success ratio was 100 percent from 1983 to 1990 (Kikuta et al., 1995). By these two samples, the author would like to understand that kumataka primarily breeds every year.

Followed reason expected is age of kumataka. That is, the kumataka has been lost their breeding power. However the kumataka of site A might be a aged couple, but old female has disappeared after having failed breeding at incubating stage (note 4 of Table 1). This female would be death around disappeared time. But it proved that old female could yield egg. And the old male which was a partner of the death female, got another young bird and make coupling next summer. This new couple had succeeded breeding at 1998. From these data we could not decided that age is a reason to drop breeding success ratio.

What is the real reason for influence to fall the breeding success ratio? The authors pay attention forest, vegetation and feeds animals for kumataka to breed. Due to kumataka is one of bird of prey lived in the forest (EA, 1991; Morimoto \& Iida, 1992; Morioka et al., 1995; Iida, 2005). Its life depends on the forest and strongly affected forest vegetation and feeds animals.

The author classified vegetation ten groups to understand the relation between kumataka and forest. We have made clearly kumataka didn't use old artificial forest (Morimoto \& Iida, 1992). And the hare survey showed that the over ten years old artificial forests have decreased a little. It is also difficult for kumataka to use 'the other land uses (village area, rice field and so on)'.

Kumataka needs wide space where they can fly and hunt animal feeds. The author confirmed the kumataka used eight types of vegetations as follow, (a) under 5 years of artificial cider and cypress forest, (b) $5 \sim 10$ years artificial cider and cypress forest, (c) Japanese red pine forest, (d) fir forest, (e) broad-leafed forest, (f) glass land, (g) harvested forest and (h) land slide area (table 3). Another important issue for kumataka is the condition surrounding their nest. The kumataka make a nest on the big old tree (Nishikaido et al., 1971; Morioka et al., 1995; EA, 1996). It needs sufficient vegetation for 
Table 3. Vegetation type and utilization expected

\begin{tabular}{lll}
\hline vegetation type & availability & \multicolumn{1}{c}{ purpose } \\
& & \\
\hline 1. under 5 yr artificial forest & available & hunting \\
2. $6 \sim 10$ yr artificila forest & available & hunting \\
3. over 10 yr artificial forest & difficult & - \\
4. Japanese red pine forest & available & hunting \& nest place \\
5. fir forest & available & hunting \& nest place \\
6. broad-leafed forest & available & hunting \& nest place \\
7. glass land & available & hunting \\
8. harvested area & available & hunting \\
9. land slide area & available & hunting \\
10. the other & difficult & - \\
\hline
\end{tabular}

kumataka to make their nest at the Japanese red pine forest, fir forest and broad-leafed forest in the survey area (Morimoto \& Iida, 1994; Morioka et al., 1995).

By the way, area of the vegetation types is very important issue. Each area of the fir forest, harvested forest, glass land and land-slide area is less than ten hectares. To the contrary, each area of over 10 years artificial forest, less than 5 years and 5 10 years artificial forest and broad-leafed forest are over 100 hectares at every site (Fig. 3-1, 2, 3). After all, important forests are five vegetation types, that is, 4 types forest shared over 100 hectares and Japanese red pine forest for keeping their nest circumstance (Table 4).

The kumataka can hunt animals in the forests and just live and use inside forests. But it is sufficient open space for flying with 1.5 meters length of its wing. And it needs hard ground for holding and grasping animals like fox (Vulpes vulpes), hare, copper pheasant and snakes with their nail. Therefore, it is better that there is nothing on the ground. The 69 percent hunting activities were seen at the under 8 years old forest and harvested one (Morimoto \& Iida, 1992).

Many hare live under ten years artificial forest where they can hide and find feeds. But over ten years artificial forest doesn't grow glass feeds so much and hare's population will be reduced to nearly zero level (Yamada, 1898). This data has indicated the same situation of our survey.

If the kumataka live in the artificial forest, the younger forest needs for kumataka to catch animal feeds. For keeping these conditions, high forestry activities are requested for long time. However the forestry activities of Hiroshima prefecture, at every site, have dropped since 1980s, due to increasing imported wood and forest products. The kumataka have affected by these forestry economy and many man-made forests were left without any care in all over Japan. The kumataka should be independent from human being but should be depend on the human being activities. This is one of ironical facts.

The table 4 shows the relations between breeding success ratio and vegetation types. The author divided two categories, one is useable forest for kumataka and the other is un-useable forest. As mentioned before, the former forests types are the over 10 years artificial forest and the other land use (village area, rice field and so on), the latter type contained the under 10 years artificial forest, Japanese pine forest, fir forest, glass land, harvested forest, broad-leafed forest and land slide area.

The usable area was bigger than un-usable area at the site A in 1980 and 1983. But since 1990s, it changed the situation and un-usable area was bigger than usable area (Fig. 3-1). The breeding success ratio at 1980s was nearly 100 percent, forestry activities was good at the same period.

The site $B$ is different conditions by site $A$. Un-usable area is bigger than usable one since 1980 (Fig. 3-2). However the kumataka had bred almost every year in 1980s, fallen every two year in 1990s but no success in 2000s.

The site $\mathrm{C}$ has been kept high success ratio in 2000s (Table 1). In this case, the usable forest area always exceeded than un-usable one. The vegetation condition is one reason why the breeding success ratio was kept high level.

The data of $\mathrm{A}$ and $\mathrm{C}$ have shown that the kumataka can't breed or can breed difficult, if the un-usable forests become to be bigger than the usable area. But the kumataka had bred every year at site B in 1980s while the un-usable area were larger than the usable one at site B in all time. For understanding this reason, the authors pay attention to the usable forest area.

The vegetation survey has carried out three times, and the usable forest area for the birds were counted 302 hectares in 1990, 232 hectares in 2000 and 247 hectares in 2005 at site A. The kumataka could not yield any eggs at these cases. On the other hand, the usable forest area for kumataka at the breeding success period was over 400 hectares, such as 461 hectares in 1980 and 444 hectares in 1983. It is as larger as the site C. That is, the usable forest area at the site $\mathrm{C}$ existed over

Table 4. classfied forest vegetation by usage for kumataka

\begin{tabular}{lll}
\hline \multicolumn{1}{c}{ category } & \multicolumn{1}{c}{ vegetation } & purpose \\
\hline usable forest & $\begin{array}{l}\text { planted (under } 5 \text { yr cider and cypress) } \\
\text { planted (6 } \sim 10 \text { yr cider and cypress) } \\
\text { red pine forest } \\
\text { broad-leafed forest }\end{array}$ & $\begin{array}{l}\text { hunting } \\
\text { hunting } \\
\text { hunting, nest places } \\
\text { hunting, nest place }\end{array}$ \\
\hline un-usable forest & planted (over 10 yr cider and cypress) & - \\
\hline $\begin{array}{l}\text { note; if people carried out thinning and pruning to over 10 year planted forest, these forest } \\
\text { will be changed an usable forest. }\end{array}$ &
\end{tabular}


580 hectares. The author understands that a minimum 400 hectares usable land needs for breeding success.

To the contrary, site B has only 25 percent of total range and its area is less than 200 hectares at the good performance for breeding. While the usable area was less than 200 hectares, the breeding of site B has succeeded from 1980s to 1990s. The author thinks the reason as followed.

The site A and C are like vegetation types and density of standing trees at 100 square meters of the over ten years forest is $7 \sim 8$ trees (average distance of trees is $3 \sim 4$ meters) at both sites (Fig. 4). But site B has $2 \sim$ 3 trees at same 100 square meters of same categories forest. A distance of trees is about $6 \sim 7.5$ meters. Besides, number of droppings of hare and living index of copper pheasant at the site B could be found much more and higher than site A. The author has understood animal feeds in the site B have been lived much more than site A. And the kumataka can fly and hunt easily in the artificial forest of site A.

By the way, domestic log price have been falling since 1980 and it is so cheap that forest owner can't get profit. Many artificial forests have been left without any care such as pruning, thinning. The kumataka faces vicious circle as follow. (1) decreasing area of young forest, (2) increasing area of old artificial forest without any care, (3) decreasing animal feeds and hunting area, (4) falling the breeding success ratio.

On the other hand, there is a usable forest and un-usable forest for kumataka. Generally broad leaf forest are welcomed for kumataka, but the broad-leafed forest without any care doesn't welcome to this bird, due to the lack of space for flying and hunting.

Diminution of hare in Japan were pointed out, it was proved that damages for agriculture and forestry crops with hare have also reduced to one seventh to one tenth of 1970s (Yamada, 1988). The population of hare have been expected decline as high speed as the damages reduced. While the kumataka hasn't deeply depended on the hare like the GE (SRGE, 1984; Morimoto \& Iida 1992, Morioka et al., 1995), but decline of the population of hare and copper pheasant means the reduction of appropriate animal feeds. In winter season, snake species took torpor, hare would be more important at that time. In generally, weight of bird of prey is the maximum at the just before laying egg, and it related to the breeding success ratio (Newton, 1986). The kumataka starts breeding at beginning of winter and lays egg at coming spring. Therefore animal feeds of winter, such as hare and copper pheasant are very important for their breeding (Morimoto \& Iida, 1992; EA, 1996). The author thought if the couple of kumataka couldn't have enough feeds at the beginning of winter, they have left breeding and might be stop by nest making stage and/or by adherence to nest forest. That is to say, if we would like to keep high breeding success ratio, we should take care the forest, such as harvesting, thinning, pruning, felling and so on. It means forestry activities should make up to 1980 s level.

\section{REFERENCES}

Environmental agency 1991 The wild animals possible of extinction in Japan. Red Data Book

Environmental agency 1996 How to preserve the raptores; in particular, Golden Eagle, Mountain Hawk Eagle, and Goshawk, (JSPB)

Fujita M. 1996 Some examples of interferences with Mountain Hawk Eagle's breeding, all over Japan, second MHE symposium, pp. $15-17$

Iida T. 1996 Mountain Hawk Eagle detailed breeding action and protection steps of nesting places, Second MHE symposium, 6-11

Iida T. 1996 Mountain Hawk Eagle - The daily life and the exsisting condition-, Nature Conservation, 408: 9-11

Iida T. 2005 Mountain Hawk Eagle, the king of forest - its body and life as one body with forest-, BIRDER, (19)2: 20-21

Ueuma Y. 1989 Mountain Hawk Eagle home range and action patterns in Hakusan zone, Hakusan Nature Conservation Center Investigation Report, 16: 23-27

JSPB 2004 The investigation report of the rare raptores (a volume of Mountain Hawk Eagle ), (Japan), pp. 364

Kikuta K., et al., 2, 1995 Mountain Hawk Eagle's inhabiting and breeding condition in Kawakami village, Nara prefecture. First MHE Symposium, pp. 4

Morimoto S. and Iida T. 1992 Ecology and preservation of Mountain Hawk Eagle (Spizaetus nipalensis), Strix, 11: 59-90

Morimoto S. and Iida T. 1994 Nest site characteristics of the Mountain Hawk Eagle (Spizaetus nipalensis) in western Hiroshima, Strix, 13: 179-190

Morioka T., et al., 3, 1995 The Birds of Prey in Japan Bun-ichi Co,. Ltd (Japan)

Newton I. 1986, The Sparrowhawk, . T and AD Poyser (GB).

Nishikaido M., et al., 3, 1971 Breeding ecology of Spizaetus nipalensis in Japan J.Yamashina Inst.Ornithology, 6: 286-299

Shigeta Y. 1979 The investigation report of natural environment in eastern Chugoku mountain zone, pp. 106-140

SRGE 1984 Food Habits of Golden Eaglis in Japan, Aquila chrysaetos, 2: 1-6

SRGE 1991 inhabiting and breedings of Golden Eagles, being influenced by developing acton, Aquila chrysaetos, 8: 1-9

SRGE 1994 The cause of failure - breedings of Golden Eagle, Aquila chrysaetos, 10: 1-10

SRGE 2001 The investigation report of the number of Golden Eagles and sucssess - breeding rate, all over Japan (1996-2000), Aquila chrysaetos, 17: 1-9

SRGE 2002 The change of home range and behavior patterns, at each stage, of Golden Eagle, Aquila chrysaetos, 18: 1-32

Sudo K. 1985 Mountain Hawk Eagle's home range and distance between nests, inhabiting northern Tanba mountain zone, Aquila chrysaetos, 3: 23

Yamada F. 1988 The reason why the rares gnaw at trees of plantation; Research Report of General Forest Institute, Kansai Branch, 10, pp. 1-4 